\title{
Fibroblasts from bank voles inhabiting Chernobyl have increased resistance against oxidative and DNA stresses
}

\author{
Venla Mustonen ${ }^{1}$, Jenni Kesäniemi ${ }^{1}$, Anton Lavrinienko ${ }^{1}$, Eugene Tukalenko², Tapio Mappes ${ }^{3}$, Phillip C. Watts ${ }^{1}$ \\ and Jaana Jurvansuu ${ }^{1 *}$ (D)
}

\begin{abstract}
Background: Elevated levels of environmental ionizing radiation can be a selective pressure for wildlife by producing reactive oxygen species and DNA damage. However, the underlying molecular mechanisms that are affected are not known.

Results: We isolated skin fibroblasts from bank voles (Myodes glareolus) inhabiting the Chernobyl nuclear power plant accident site where background radiation levels are about 100 times greater than in uncontaminated areas. After a 10 Gy dose of gamma radiation fibroblasts from Chernobyl animals recovered faster than fibroblasts isolated from bank voles living in uncontaminated control area. The Chernobyl fibroblasts were able to sustain significantly higher doses of an oxidant and they had, on average, a higher total antioxidant capacity than the control fibroblasts. Furthermore, the Chernobyl fibroblasts were also significantly more resistant than the control fibroblasts to continuous exposure to three DNA damaging drugs. After drug treatment transcription of p53-target gene proapoptotic Bax was higher in the control than in the Chernobyl fibroblasts.
\end{abstract}

Conclusion: Fibroblasts isolated from bank voles inhabiting Chernobyl nuclear power plant accident site show elevated antioxidant levels, lower sensitivity to apoptosis, and increased resistance against oxidative and DNA stresses. These cellular qualities may help bank voles inhabiting Chernobyl to cope with environmental radioactivity.

Keywords: Bank vole, Chernobyl, Environmental ionizing radiation, p53, DNA damage, Antioxidant capacity

\section{Background}

The Chernobyl nuclear power plant disaster in 1986 was classified by the International Atomic Energy Agency to the most severe radiation accident level. Since then, the most contaminated area around the nuclear power plant has been closed to the general public. This Chernobyl exclusion zone covers about $2600 \mathrm{~km}^{2}$ and still contains patches of radioactively contaminated soil emitting from normal background levels of $0.2 \mu \mathrm{Sv} / \mathrm{h}$ up to about $200 \mu \mathrm{Sv} / \mathrm{h}$ [1].

A meta-analysis has shown that ionizing radiation has increased mutation frequency in various Chernobyl taxa as represented by, for example, discolorations, cataracts, chromosomal abnormalities, or cancers [2].

\footnotetext{
* Correspondence: jaana.jurvansuu@oulu.fi

${ }^{1}$ Department of Ecology and Genetics, University of Oulu, Fl-90014 Oulu, Finland

Full list of author information is available at the end of the article
}

Another meta-analysis on wildlife inhabiting Chernobyl area found a small to intermediate increase in oxidative damage (such as imbalance between oxidants and antioxidants) and a decrease in antioxidant defenses (such as depleted antioxidant levels) [3]. However, the prevalence of these effects varied among species, implying that there is no standard response to chronic low-dose radiation and that some species are more radioresistant than others. Accordingly, the species abundance in Chernobyl area has been reported to be in decline, constant, and on rise, due to either the adverse effects of ionizing radiation or because of lack of detrimental human activity [4-7]. Furthermore, evidence for an adaptive response to chronic low-dose radiation at Chernobyl is somewhat equivocal [8]. Nonetheless, adaptation has been reported in plants: plants within Chernobyl area have higher resistance to DNA-damaging chemicals, antioxidants, osmotic stress, and gamma irradiation 
than control plants and have also changes in antioxidant and stress responses, and in DNA repair [9-11].

The bank vole (Myodes glareolus) is an ideal mammalian model to study the effects of environmental radiation in Chernobyl, because it is common at the site, remains close to the surface source of radiation, and as a small animal has relatively small territory. Bank vole population sizes were very low following the accident at Chernobyl but numbers of this species rebounded during the following year, probably via immigration from several nearby populations $[12,13]$. Since the accident, Chernobyl bank voles have been shown to harbor slight but significant increase in amounts of chromosomal aberrations, mitochondrial DNA mutations, and cataracts in females, yet other work has found no signs of genotoxic stress [14-17].

Ionizing radiation can cause long-lasting and inherited effects by damaging DNA directly or via water-derived free radicals. To determine whether exposure to chronic low-dose radiation extending possibly several generations has affected bank vole cells' ability to tolerate oxidative and DNA stress we isolated skin fibroblasts from bank voles from the Chernobyl exclusion zone and from an uncontaminated control area near Kiev. We chose to study skin fibroblasts because they are easy to isolate even in field conditions. The fibroblasts were challenged with gamma radiation to study their reactions to the original type of stress, and with an oxidative agent and three DNA damaging drugs to dissect the responses to two biologically important aspects of ionizing radiation: oxidative stress and DNA damage. In all treatments, Chernobyl fibroblasts were, on average, able to sustain the insults better than the control fibroblasts. Moreover, Chernobyl fibroblasts had higher total antioxidant capacity than the control cells and were less sensitive to DNA damage induced lethality, both of which processes may explain their increased resistance against radiation.

\section{Results}

\section{Chernobyl fibroblasts recover after $10 \mathrm{~Gy}$ irradiation faster than control fibroblasts}

Skin fibroblasts were isolated from eight male bank voles from the Chernobyl exclusion zone (an average dose rate of $21 \mu \mathrm{Sv} / \mathrm{h}$ ) and from an uncontaminated control area near Kiev (an average dose rate of $0.2 \mu \mathrm{Sv} / \mathrm{h}$ ). The same number of fibroblasts for each cell line were irradiated at the rate of $3.5 \mathrm{~Gy} / \mathrm{min}$ from a cesium-137 source. The cells were allowed to recover for $24 \mathrm{~h}$ and then replated to a flask with about 4.5 times bigger growth surface area. After $24 \mathrm{~h}$ of the irradiation, we did not see increase in apoptotic or floating dead cells in any of the cell lines and thus we chose a growth based assay instead of a viability test to study the cells. A clonogenic survival assay, typical for these kind of experiments, was not suitable for these primary fibroblasts because they readily die if plated too scarcely. Recovery date was scored when cells reached $100 \%$ confluency. The delay of recovery (Fig. 1) was calculated by how many days longer the irradiated cell line took to reach confluency in comparison to the untreated cell line. Fibroblasts from Chernobyl animals were significantly (Student's t-test $p$-value $=0.028$ ) faster to recover after the irradiation than fibroblasts from control animals. Control fibroblasts took on average 9.2 days longer to fill the plate after 10 Gy irradiation whereas Chernobyl cells took just 6.8 days longer than the corresponding untreated cell lines.

\section{Chernobyl fibroblasts grow in higher concentrations of oxidant and have higher total antioxidant capacity than control fibroblasts}

To determine whether Chernobyl fibroblasts are more resistant to the oxidative or the DNA damaging effect of radiation we first studied the effect of the oxidant tert-butyl hydroperoxide on the cells. Cells were plated on 24 well plates at $80 \%$ confluency and exposed to different concentrations $(50-150 \mu \mathrm{M})$ of tert-butyl hydroperoxide for $24 \mathrm{~h}$ before changing the media. Cells were allowed to grow for a week and then 100\% confluent wells were scored (Fig. 2a). Chernobyl fibroblasts were able to recover and grow in about $40 \mu \mathrm{M}$ higher concentration of the oxidant than the control fibroblasts $\left(\mathrm{x}_{\mathrm{CTRL}}=66.7 \mu \mathrm{M}, \mathrm{x}_{\mathrm{CHERNO}}\right.$ $\mathrm{BYL}=108.3 \mu \mathrm{M}$, Student's t-test $p$-value $=0.0096)$. We also tested whether the cells would differ in response to constant exposure to small concentrations $(10-50 \mu \mathrm{M})$ of the oxidant added every other day for four times but both

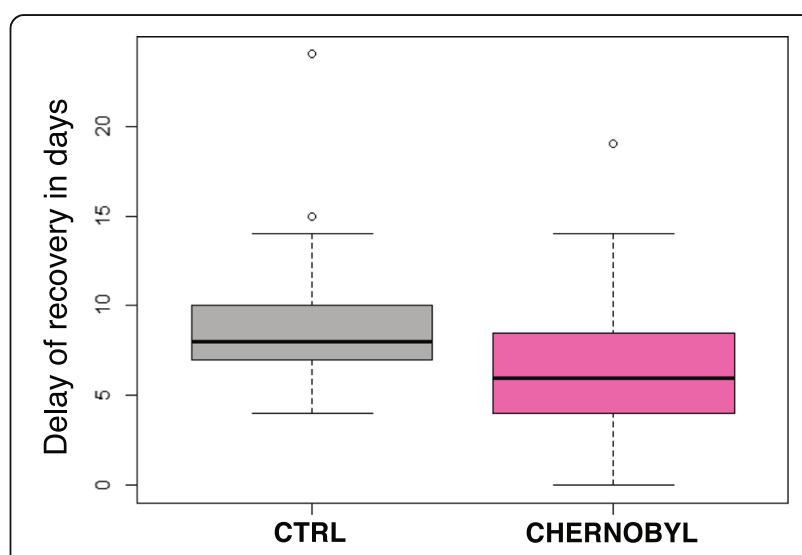

Fig. 1 Chernobyl bank vole fibroblasts recover faster after irradiation than control cell lines. The fibroblast cell lines isolated from Chernobyl bank voles (pink) were able to reach 100\% confluency, on average, 2 days faster than the control cell lines (grey) after 10 Gy irradiation. "The delay of recovery" represents how many days longer an irradiated cell line took to cover the plate than the

corresponding non-irradiated cell line. The figure shows results from three separate experiments using eight Chernobyl $(N=24)$ and eight control $(N=24)$ cell lines. In the box blot the box presents the lower and upper quartiles, median is indicated by a line, whiskers show values within 1.5 interquartile range from the boxed values, and circles are outliers ( $R$ version 3.3.3) 


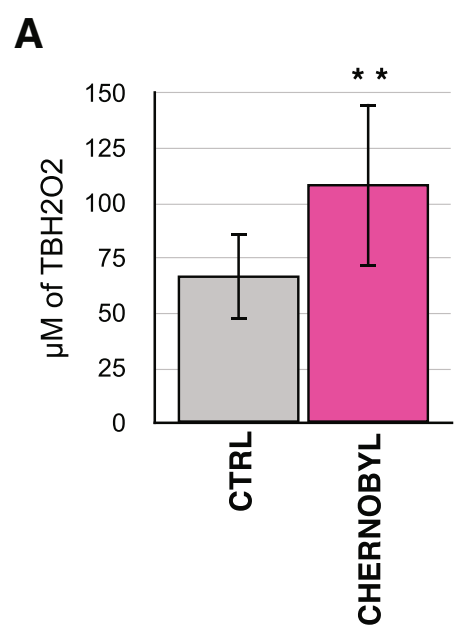

B

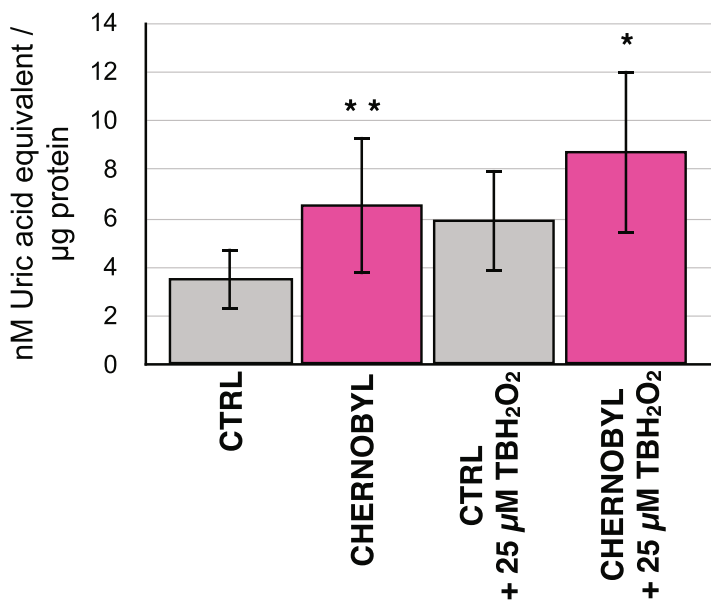

Fig. 2 Chernobyl fibroblasts survive in higher oxidant concentration and have more antioxidants than control fibroblasts. a Fibroblasts isolated from Chernobyl bank voles were, on average, able to grow in about $40 \mu \mathrm{M}$ higher concentration of oxidizing agent tert-butyl hydroperoxide (TBH2O2) than control bank vole fibroblasts. Cells were treated with different concentrations of the oxidant for $24 \mathrm{~h}$ after which fresh cell culture media was changed and cells were let grow for 7 days before scoring the wells that remained $100 \%$ confluent. b. Chernobyl fibroblasts have significantly higher total antioxidant capacity in untreated and oxidant-treated cells than control fibroblasts. For oxidant treatment cells were grown in $25 \mu \mathrm{M}$ of $\mathrm{TBH} 2 \mathrm{O} 2$ for $24 \mathrm{~h}$ before the total antioxidant capacity was measured. Results are from three separate experiments using eight Chernobyl $(N=24)$ and eight control $(N=24)$ cell lines, variation is shown by standard deviation, and statistical analysis was done with Student's t-test $\left(* 0 \leq 0.05,{ }^{* *}=p \leq 0.01\right)$

groups, except one control cell line, were able to adjust and grew in all the concentrations (Additional file 1).

To assess if Chernobyl fibroblasts tolerate more oxidant because they had more antioxidants, total antioxidant levels were measured by cell extracts' capacity to reduce copper. Cell extracts from cells grown in normal conditions or after $24 \mathrm{~h}$ challenge with $25 \mu \mathrm{M}$ of tert-butyl hydroperoxide we tested (Fig. 2b). On average, Chernobyl fibroblasts had almost twice the total antioxidant capacity in normal cell culture conditions than the control cells $\left(\mathrm{x}_{\mathrm{CTRL}}=3.5 \mathrm{nM} / \mu \mathrm{g}\right.$, $\mathrm{x}_{\text {CHERNOBYL }}=6.5 \mathrm{nM} / \mu \mathrm{g}, p$-value $=0.010$ ). Total antioxidant capacity in the oxidant-challenged cell lines was greater than in unchallenged cell lines in both groups and the increase was similar: 2.4 and 2.2 units for control and Chernobyl cells, respectively. The similar level of antioxidant induction in the two groups suggests that regulatory responses in Chernobyl fibroblasts were intact. However, Chernobyl fibroblasts had still significantly higher total antioxidant capacity $(p$-value $=0.041)$ than the control cells after the antioxidant treatment. The higher basal antioxidant levels in Chernobyl fibroblasts may protect the cells against excess oxidants generated by ionizing radiation exposure.

\section{Chernobyl fibroblasts grow in higher concentrations of DNA damaging drugs than control fibroblasts}

We tested the bank vole fibroblasts' ability to withstand DNA damage by exposing cells to DNA cross-linking drug cisplatin, DNA-intercalating drug doxorubicin, and topoisomerase inhibitor etoposide. Cisplatin adducts are repaired mainly by nucleotide excision repair whereas doxorubicin and etoposide produce double-strand breaks that are subject to homologous recombination [18]. Cells were plated at $80 \%$ confluence and treated with different concentrations of the drugs for $24 \mathrm{~h}$ before replacing the media. The cells were allowed to grow for a week before scoring the concentration where they were able to grow to $100 \%$ confluency. Chernobyl fibroblasts tolerated significantly more of etoposide than the control cells $\left(\mathrm{x}_{\mathrm{CTRL}}=\right.$ $44.1 \mu \mathrm{M}, \mathrm{x}_{\text {CHERNOBYL }}=83.6 \mu \mathrm{M}$, Student's $\mathrm{t}$-test $p$-value $=$ 0.004; Fig. 3c). Yet there was no significant differences between the groups to the other drug treatments (Fig. 3a and b). Because a constant small amount of DNA damage is more appropriate condition to mimic the environmental radiation to which the Chernobyl bank voles are exposed, we treated the cells with low concentrations of the drugs every other day for four times and recorded the $100 \%$ confluent wells a day after the last treatment. Chernobyl cells were significantly more resistant to all DNA damaging drugs (Fig. 3d to f), especially doxorubicin and etoposide (Fig. 3e and f), than the control cells. On average, the Chernobyl fibroblasts were able to grow in over four times higher doxorubicin concentrations than the control cell lines $\left(\mathrm{x}_{\mathrm{CTRL}}=2.2 \mu \mathrm{M}, \mathrm{x}_{\mathrm{CHERNOBYL}}=\right.$ $9.0 \mu \mathrm{M}, p$-value $<0.0001)$. The difference in tolerance between Chernobyl and control cells treated with etoposide $\left(\mathrm{x}_{\mathrm{CTRL}}=14.6 \mu \mathrm{M}, \mathrm{x}_{\mathrm{CHERNOBYL}}=27.5 . \mu \mathrm{M}, p\right.$-value $=0.0015$; Fig. 3f $)$ and cisplatin $\left(\mathrm{x}_{\mathrm{CTRL}}=13.1 \mu \mathrm{M}, \mathrm{x}_{\mathrm{CHERNOBYL}}=\right.$ 

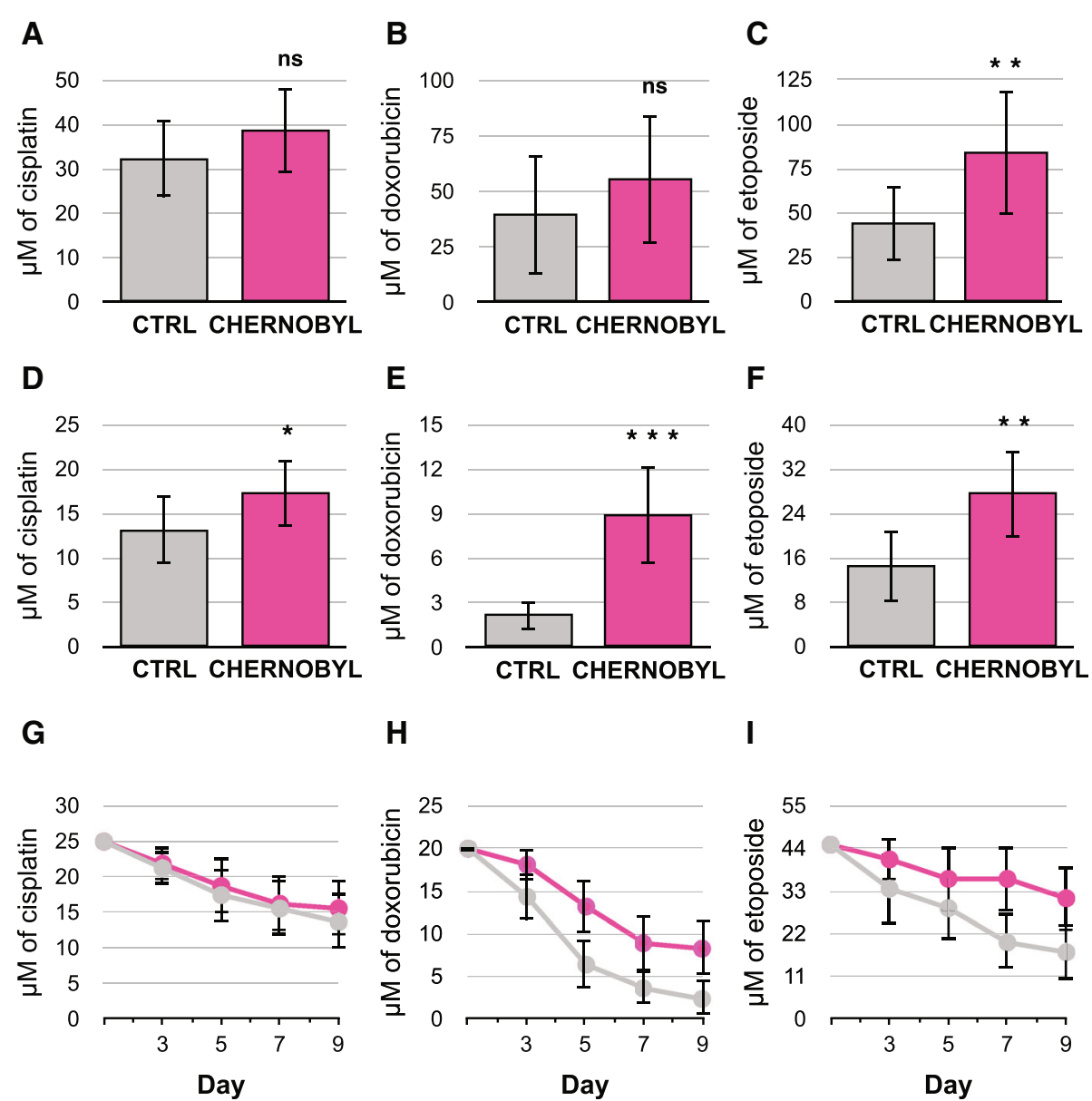

I

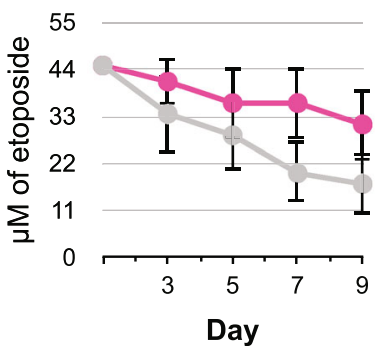

Fig. 3 Chernobyl bank vole fibroblasts survive on higher concentrations of DNA damaging drugs than control cells. Cells were plated at $80 \%$ confluency and treated with different concentrations of the DNA damaging drugs for $24 \mathrm{~h}$ after which fresh cell culture media was changed and the cells were let to grow for 7 days before scoring the wells that were $100 \%$ confluent. Treatment with a.) cisplatin or b.) doxorubicin did not show significant difference between the Chernobyl and control cell lines, whereas Chernobyl cells were able to grow in, on average, about $30 \mu \mathrm{M}$ higher concentrations of c.) etoposide. For constant exposure of DNA damaging drugs cells were treated with the drug every other day for four times before scoring the wells that were $100 \%$ confluent. Chernobyl fibroblasts were able to grow in significantly higher chronic concentrations of D.) cisplatin, e.) doxorubicin and f.) etoposide than control cells. Examples from one experiment $(\mathrm{N}=8)$ on the effect of constant drug treatment on reduction of $100 \%$ confluent Chernobyl and control fibroblast cultures after treatment with $\mathbf{g}$.) cisplatin, $\mathbf{h}$.) doxorubicin, and $\mathbf{i}$.) etoposide. Results, except $\mathbf{g}$-i, are from three separate experiments using eight Chernobyl $(N=24)$ and eight control $(N=24)$ cell lines, variation is shown by standard deviation, and statistical analysis was done with Student's t-test (ns $=p>0.05,{ }^{*}=p \leq 0.05,{ }^{* *}=p \leq 0.01,{ }^{* *}=p \leq 0.001$ )

17.2 $\mu \mathrm{M}, p$-value $=0.018$; Fig. 3e) were smaller but still significant. Chernobyl cells seemed more tolerant to dsDNA break producing drugs doxorubicin and etoposide than to cisplatin-derived adducts. In contrast to oxidant exposure, cells were incapable of adjusting to constant dose of DNA damaging drugs: the longer the cells were treated with the drugs, the more sensitive they became as shown by the chronic dose experiment where the $100 \%$ confluent wells were recorded a day after every treatment (Fig. 3g to i).

\section{After DNA damage Chernobyl fibroblasts remain arrested at $\mathrm{G} 2$ whereas control fibroblasts die}

Chernobyl fibroblasts might withstand higher concentrations of DNA damaging drugs because they either had enhanced DNA repair capacity or were able to arrest longer to repair the damage. We tested the fibroblasts' ability to repair DNA damage by host-cell reactivation assay on oxidized, nicked, and linearized plasmid substrates. Our results showed that there was no significant difference in repair efficiencies between Chernobyl and control fibroblasts (Additional file 2). Next, we tested the cell cycle effects of etoposide-mediated DNA damage on the fibroblasts. We treated cells with $20 \mu \mathrm{M}$ of etoposide for $24 \mathrm{~h}$ and collected samples 24,48 , and $72 \mathrm{~h}$ from the start of the treatment for propidium iodide flow cytometry. Most of the cells arrested at the G2 phase (with $2 \mathrm{~N}$ DNA content) within $24 \mathrm{~h}$ after treatment. The control cells started to die (sub-G1) visibly more 2 days after the 
treatment (Fig. 4a and b). Etoposide is known to cause apoptosis [18] and according to Annexin V staining this was also observed in bank vole fibroblasts (Additional file 3). On average, Chernobyl fibroblasts were able to stay arrested at G2 longer than the control cell lines and thus avoiding cell death (Fig. 4c). Significantly more control cells were dying already $24 \mathrm{~h}$ after the treatment $\left(\mathrm{x}_{\mathrm{CTRL}}=6.5 \%\right.$, $\mathrm{x}_{\mathrm{CHER}}$ NOBYL $=3.0 \%$, Student's t-test $p$-value $=0.001)$ and after 2 days there was, on average, about three times as many control cells dying as Chernobyl cells $\left(\mathrm{x}_{\mathrm{CTRL}}=17.5 \%, \mathrm{x}_{\text {CHERNO- }}\right.$ $\mathrm{BYL}=6.9 \%, p$-value $=0.00008$ ). There were no significant differences between the cell lines in amount of cells remaining at G1 (i.e., with $1 \mathrm{~N}$ DNA content) at any time point. The control cells' inability to remain at G2 phase together with the observation of their increased cell death suggests that Chernobyl fibroblasts may have an intact DNA damage signaling pathway that leads to cell cycle arrest and lower sensitivity to apoptosis.

\section{After DNA damage p53-target transcripts are induced more in control than in Chernobyl fibroblasts}

Activation of transcription factor $\mathrm{p} 53$ by DNA damage can lead to apoptosis, senescence or cell cycle arrest. We collected etoposide-treated ( $20 \mu \mathrm{M}$ of etoposide for $24 \mathrm{~h}$ ) samples 48 and $72 \mathrm{~h}$ post-treatment for cDNA preparation. We quantified the transcript levels of p53-target genes: cell cycle regulators p 21 and Gadd $45 \alpha$, pro-apoptotic proteins Puma and Bax, and p53-inhibitor Mdm2 and standardized them to beta-actin transcripts. Results are shown as fold change from untreated sample (Fig. 5). Induction of Bax and Mdm2 was significantly higher at both time points in control fibroblasts in comparison to Chernobyl cells $\left(p\right.$-value BAX-48h $=0.0021, p$-value $_{\text {BAX-72h }}=$

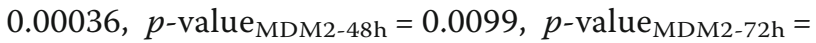
0.00096; Fig. $5 \mathrm{c}$ and e). P21 was significantly more induced in control than Chernobyl cells at $48 \mathrm{~h}(p$-value $=$ 0.028 ; Fig. $5 \mathrm{a}$ ) and Gadd $45 \alpha$ at $72 \mathrm{~h}$ time point ( $p$-value $=$ 0.0016, Fig. 5b). No significant differences in Puma induction levels were detected at either time point (Fig. 5d). The amount of pro-apoptotic Bax transcript induction was about 20\% higher in control than in Chernobyl cell lines, which is consistent with the higher percentage of dying control cells seen in the flow cytometry experiment.

\section{Discussion}

Fibroblasts from Chernobyl bank voles were, on average, more resistant to radiation, oxidant treatment and DNA damaging drugs than the control fibroblasts. The DNA damaging drugs we used, etoposide, doxorubicin, and cisplatin have all been suggested to cause oxidant byproducts [19-21], thus the higher antioxidant levels of the Chernobyl fibroblasts' may have also protected them against the indirect effects of these DNA damaging drugs. Neither control nor Chernobyl cell lines were homogenous in their responses to any of the experimental treatments; there were always one or two moderately resistant control and sensitive Chernobyl cell line, as is evident from the large variance of the experiments. This variability may indicate that the resistant traits are naturally occurring genetic variations. Bank vole populations at Chernobyl are from many different source populations and thus do host much genetic variation that may provide useful adaptive traits [12, 22].

Our results suggest that the environmental radiation in Chernobyl may select for adaptive cellular qualities in bank voles that defend against oxidants and help recover from DNA damage. However, statistical support for population level adaptation would require larger sample sizes from several different bank vole populations. Nevertheless, no-one has yet presented changed nucleotide substitution rates in the nuclear genomes of any Chernobyl inhabiting organisms. Mutations, as manifested by chromosomal abnormalities and phenotypic changes, have been reported in diverse Chernobyl taxa [2]. Although Baker et al. [17] have shown increased mutation rate of mitochondrial genomes in bank voles inhabiting Chernobyl, the results are not directly applicable to the nuclear genome because of differences in the DNA repair mechanisms and oxidative processes and conditions between nucleus and mitochondria. We found that Chernobyl fibroblasts withstood especially well chronic doses of dsDNA break inducing drugs (doxorubicin and etoposide) and, unlike control fibroblasts, they were able to stably arrest after DNA damage at G2 phase, when homologous recombination, the most accurate mechanism to repair dsDNA breaks, is most active. Thus, the implication of our results is the potential for bank vole cells to mount an efficient cellular mechanism against DNA breaks produced by radiation.

Chernobyl fibroblasts had more antioxidants in standard cell culture conditions than control cells and they were able to grow in higher oxidant concentrations. Chernobyl bank voles' darker fur was hypothesized by Boratyński et al. [23] to be indicative of preferential production of eumelanin instead of pheomelanin, of which biosynthesis reduces reserves of antioxidant glutathione. Galván et al. [24] showed that Chernobyl birds living in areas of high radiation have increased glutathione levels, which correlated positively with improved body condition and reduced DNA damage. The antioxidant levels in Chernobyl birds have also been reported to be depleted, possibly due to the chronic radiation exposure leading to increased amounts of oxygen radicals $[25,26]$. The unchallenged antioxidant levels were not tested in these ecological studies, but the results do suggest that antioxidants are one of the key factors in response against environmental radiation. Cells raise antioxidant levels following oxidant exposure and this reaction has been shown to be a crucial cellular response against low-dose radiation [27, 28]. Consequently, priming cells with oxidant 
A
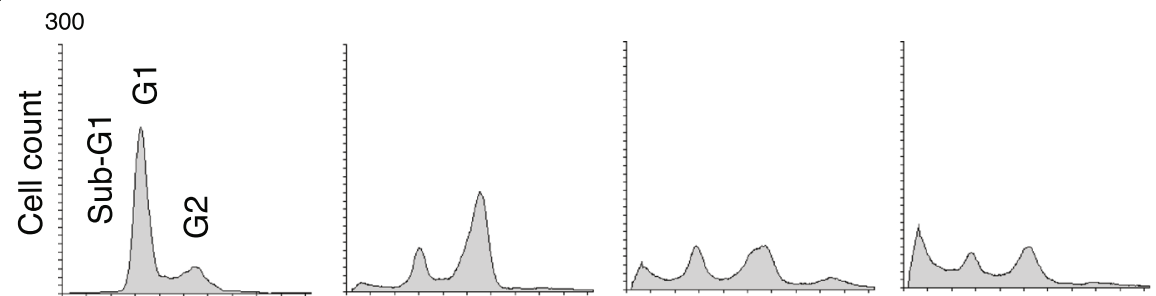

B

DNA content
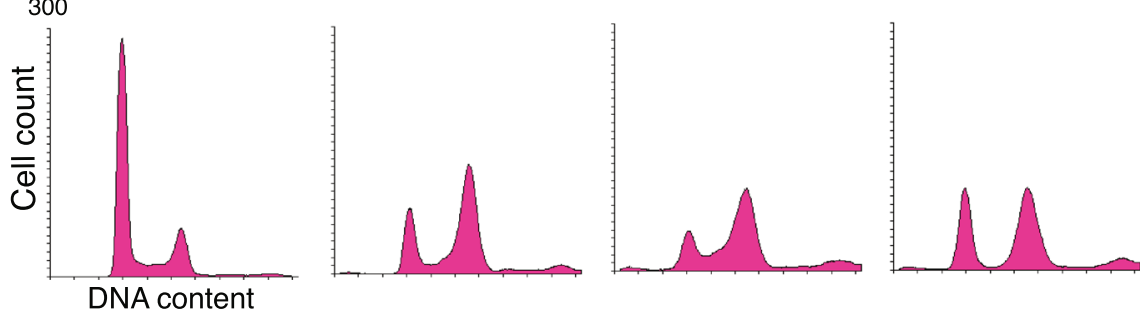

Oh

24h

$48 h$

$72 h$

C

G1

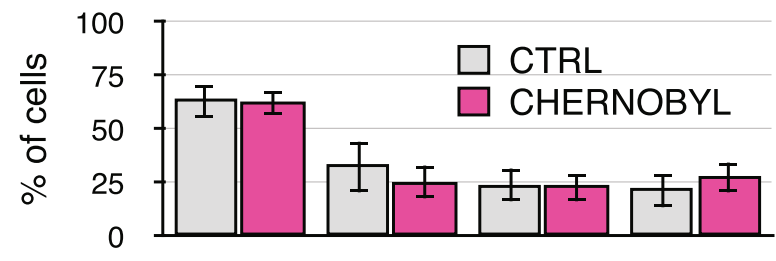

G2

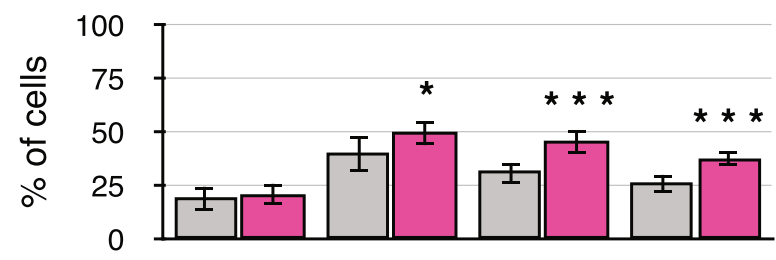

Sub-G1

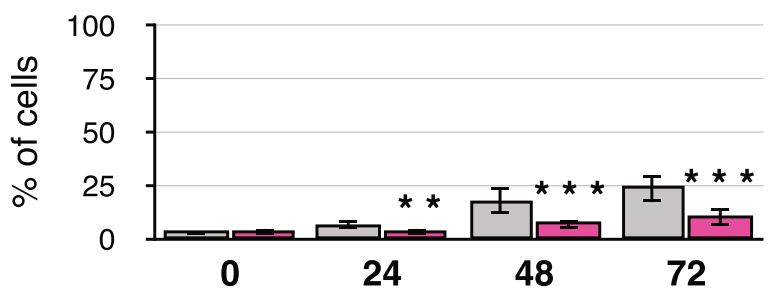

Hours post-etoposide treatment

Fig. 4 After DNA damage Chernobyl fibroblasts arrest stably at G2 phase. Example propidium iodide flow cytometry profile for one a.) control and $\mathbf{b}$. Chernobyl cell line after 24, 48, and 72 h from etaposide treatment. c. The bar charts show the percentage of cells in G1, G2, and sub-G1 cell cycle phase for Chernobyl and control fibroblasts according to their DNA content by flow cytometry after 24, 48, and $72 \mathrm{~h}$ from etoposide treatment. The location of cells in sub-G1 (dying cells), G1, and G2 cell cycle phase are marked in the DNA histogram. The bar chart results are from three separate experiments using eight Chernobyl $(N=24)$ and eight control $(N=24)$ cell lines, variation is shown by standard deviation, and statistical analysis was done with Student's t-test $\left(^{*}=p \leq 0.05,{ }^{* *}=p \leq 0.01,{ }^{* * *}=p \leq 0.001\right)$ 
A

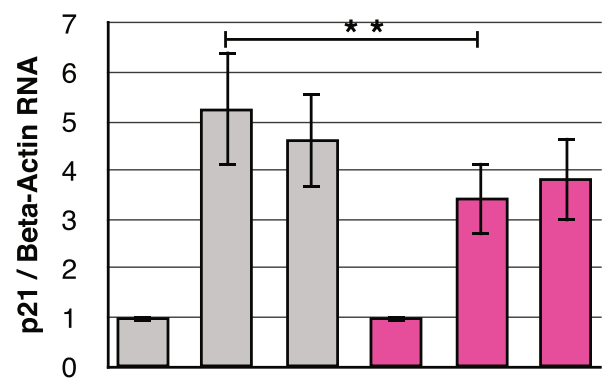

B

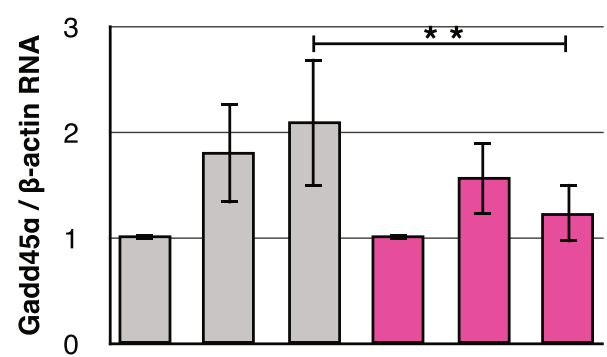

C

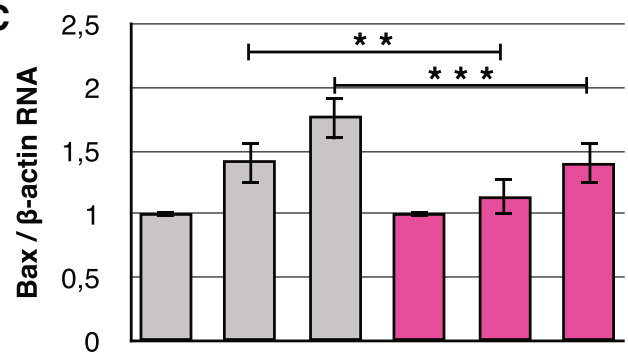

D

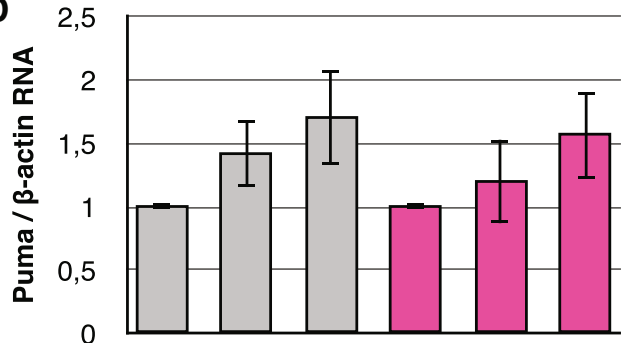

E

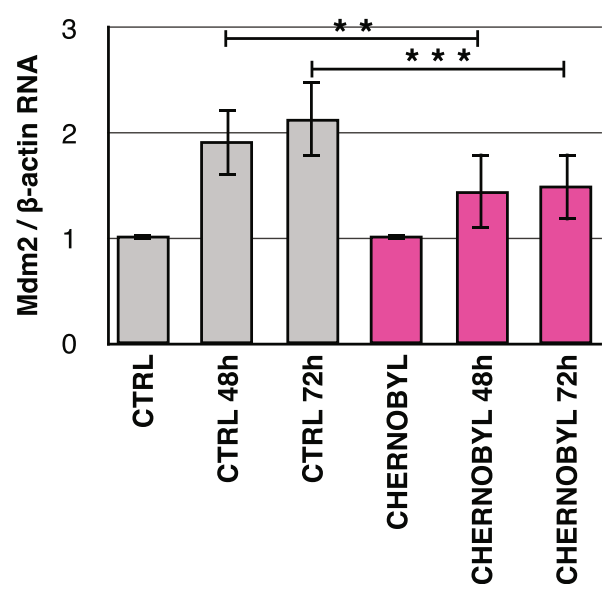

Fig. 5 P53-target genes are induced more strongly in control cells than in Chernobyl bank vole fibroblasts. RNA was collected from untreated and etoposide-treated ( $20 \mu \mathrm{M})$ cells 48 and $72 \mathrm{~h}$ after the drug treatment. CDNA was prepared and quantitative-PCR was run with gene specific primers, and transcript levels were standardized to beta-actin transcript. Results are shown as a fold increase from untreated samples for a.) p21, b.) Gadd45a, c.) Bax, d.) Puma, and e.) $M d m 2$. The results are from three separate experiments using the eight Chernobyl $(N=24)$ and eight control cell lines $(N=24)$,

variation is shown by standard deviation, and statistical analysis was done with Student's t-test $\left({ }^{* *}=p \leq 0.01,{ }^{* *}=p \leq 0.001\right)$

or irradiation that increases antioxidant levels has shown to protect cells from a second exposure to radiation [27, 29]. Our results show that Chernobyl bank vole fibroblasts seem to be primed against abnormally high levels of oxidants.

P53 is a transcription factor and its activity (or lack of it) after genotoxic stress often determines whether the cell will arrest, commit apoptosis, or proceed into senescence (or mitotic catastrophe). P53 is activated by phosphorylation and the length and level of the activation together with other regulatory factors and cellular condition will decide cell fate. Low-dose chronic radiation has been shown to activate p53 and induce premature senescence in primary endothelial cells and fibroblasts $[28,30]$. After p53 activating etoposide treatment Chernobyl cells were able to arrest stably at G2 whereas control cells started to die. Our results suggest that the higher induction levels of pro-apoptotic Bax were sufficient to induce apoptosis in control cell lines yet the lower levels of cell cycle regulators, p21 and Gadd45 $\alpha$, were high enough for the Chernobyl fibroblasts to remain at G2. Similar changes in amounts of p53-target gene transcripts have had a major impact on cell death in cancer cell lines with mutated p53 $[31,32]$. Furthermore, p53 has been shown to have a role also in population level adaptation of mole rats to hypoxic environments [33]. However, in 1999 DeWoody [34] examined a short segment of Chernobyl bank voles' p53 gene and found no apparent genetic changes in the sequence.

\section{Conclusions}

Compared to control fibroblasts, fibroblasts isolated from bank voles inhabiting Chernobyl nuclear power plant accident site have elevated basal antioxidant levels and show decrease susceptibility to apoptosis after DNA damaging treatment. Accordingly, the Chernobyl fibroblasts were more resistant against oxidative and chronic DNA stresses.

Environmental radiation research is complicated by numerous interactions between exposed animal and its exposed environment. Meta-analysis has shown that organisms inhabiting Chernobyl area are approximately eight times more sensitive to radiation than species exposed to similar levels of radiation in controlled laboratory experiments [35]. Thus, the harmful effects of radiation apparently escalate with increased biological interaction and 
complexity. These ecological interactions might explain why some bank voles inhabiting Chernobyl nuclear accident site have two cellular mechanisms, high antioxidant levels and insensitivity to apoptosis, to cope with seemingly minor excess of environmental radiation.

\section{Methods \\ Cells}

Cells were isolated from eight male bank voles from the Chernobyl exclusion zone (GPS coordinates N51.44536 E30.06522) and eight male voles from Kiev area (N50.525859 E30.436933) (Additional file 4). Bank voles were caught using Ugglan Special2 multiple-capture live traps (Grahnab, Sweden) during June of 2016. The level of soil radiation at the trapping sites were measured at one $\mathrm{cm}$ above the ground using a Geiger-Mueller dosimeter (Inspector, International Medcom INC). Selected bank voles were of similar size (length: $\mathrm{x}_{\mathrm{CTRL}}=$ $24.5 \mathrm{~cm}, \mathrm{x}_{\text {CHERNOBYL }}=21.9 \mathrm{~cm}$, Student's t-test $p$-value $=0.06$; weight: $\mathrm{x}_{\mathrm{CTRL}}=88.7 \mathrm{~g}, \mathrm{x}_{\mathrm{CHERNOBYL}}=92.1 \mathrm{~g}$ Student's t-test $p$-value $=0.08$ ). Animals were euthanized by cervical dislocation and all the procedures were performed in accordance with international guidelines and regulations for the use of animals in research. The study was approved by the Finnish Ethical Committee (license number ESAVI/7256/04.10.07/2014).

Skin fibroblasts were isolated 1-4 $\mathrm{h}$ after the animals were sacrificed according to the protocol of Seluanov [36]. In short, about one $\mathrm{cm}^{2}$ area of shaved skin from armpit of the animal was clipped and put into PBS for $10 \mathrm{~min}$ and then cut into small pieces and incubated at $37^{\circ} \mathrm{C}$ in DMEM (30\%) / PBS (70\%) / Liberase DL Research Grade Enzyme $(500 \mu \mathrm{g} / \mathrm{ml})$ (Sigma-Aldrich) for $30 \mathrm{~min}$. The tissue was filtered through $70 \mu \mathrm{m}$ nylon mesh and placed into cell culture tube with DMEM (high glucose, Gluta$\left.\mathrm{MAX}^{\mathrm{si}}\right)$ / 20\% FBS / penicillin $(100 \mathrm{U} / \mathrm{ml})$ / streptomycin $(100 \mu \mathrm{g} / \mathrm{ml}) /$ amphotericin B $(1 \mu \mathrm{g} / \mathrm{ml})$ (all from Thermofisher) and incubated at $37^{\circ} \mathrm{C}$ for 2 days.

Cells were routinely cultured at $36^{\circ} \mathrm{C} / 80 \%$ humidity / $5 \% \mathrm{CO}_{2}$ in DMEM / 10\% FBS / penicillin / streptomycin / amphotericin B. All experiment were done with similar passage numbers for both control and Chernobyl cells between passages 5-30. After cell passage 30 some of the cell lines showed chromosomal number abnormalities.

\section{Cell treatments}

For cell treatments, 20,000 cells were plated to 24 well plates and let grow for 1 day to about $80 \%$ confluency before the treatment. Tert-butyl hydroperoxide (Alfa Aesar) was diluted in PBS and added to cells at concentrations of $150,125,100,75$, and $50 \mu \mathrm{M}$ for one dose experiments and at $50,40,30,20$, and $10 \mu \mathrm{M}$ for long exposure. Cisplatin (Sigma-Aldrich) was solubilized into $0.90 \% \mathrm{NaCl}$ and added to cells at concentrations of $50,40,30,20$, and
$10 \mu \mathrm{M}$ for one dose experiments and at $25,20,15,10$, and $5 \mu \mathrm{M}$ for long exposure. Doxorubicin (Sigma-Aldrich) was solubilized into DMSO and added to the cells at concentration of $160,80,40,20,10 \mu \mathrm{M}$ for one dose experiments and at 20, 15, 10, 5, $1 \mu \mathrm{M}$ for long exposure. Etoposide (Cayman Chemical) was solubilized into DMSO and added to cells at concentrations of 200, 100, 50, 25, and $12.5 \mu \mathrm{M}$ for one dose experiments and at $45,35,25,15$, and $5 \mu \mathrm{M}$ for long exposure. For one dose experiments the cells were incubated in the drug for $24 \mathrm{~h}$ after which fresh media was changed and cells were let to recover for 7 days before scoring the $100 \%$ confluent wells. For longer exposures, cells were treated with the drug every other day for four times by removing the old media and adding a new drug dose in fresh media. The $100 \%$ confluent wells were scored a day after the last treatment. Experimental controls were treated only with the drug solubilization solution.

For irradiation 20,000 cells were plated to cell culture tubes (NuncTM) and irradiated the next day with $10 \mathrm{~Gy}$ at the rate of $3.5 \mathrm{~Gy} / \mathrm{min}$ from Cesium-137 source (Gammacell 2000). The cells were allowed to recover from the irradiation for $24 \mathrm{~h}$ and then replated to $25 \mathrm{~cm}^{2}$ plates. Cells were allowed to grow until they were $100 \%$ confluent.

\section{Total antioxidant assay}

For each cell line, 40,000 cells were plated on 6 well plates and allowed to grow for 2 days before adding tert-butyl hydroperoxide for final concentration of $25 \mu \mathrm{M}$ (or the same volume of PBS to experimental controls). Total antioxidant levels were measured $24 \mathrm{~h}$ after the treatment with OxiSelectTM Total Antioxidant Capacity Assay kit (Cell Biolabs) and the protein concentration was measured with Bio-Rad Protein Assay.

\section{Host-cell reactivation assay}

Five thousand cells were plated on 96 well plate, treated next day with $20 \mu \mathrm{M}$ etoposide for 8 hours, and then transfected with pGL3 (Promega) plasmid treated either with $\mathrm{Nb}$.BsmI that nicked the plasmid coding sequence three times, with HindIII that linearized the plasmid after promoter sequence, or with $50 \mu \mathrm{M}$ FeSO4 and $1 \mathrm{mM} \mathrm{H} 2 \mathrm{O} 2$, which created oxidative damage on the plasmid. To control transfection efficiency cells were transfected also with pNL1.1 nano-luc vector. Luciferase expression was analysed $24 \mathrm{~h}$ after transfection with Nano-Glo Dual-Luciferase reporter assay system as suggested by the manufacturer (Promega).

\section{Quantitative-PCR}

Total RNA was isolated with TRIzol ${ }^{\circ}$ Reagent (Thermofisher) as suggested by the manufacturer. CDNA was prepared from $0.5 \mu \mathrm{g}$ of RNA using RevertAid $\mathrm{H}$ Minus First Strand cDNA Synthesis Kit (Thermofisher) with random 
primers as suggested by the manufacturer. Quantitative-PCR was done with $5 \times x_{\text {HOT FIREPOL }}^{\circ}$ Evagreen $^{\circ}$ qPCR Mix Plus (SolisBiodyne) as suggested by the manufacturer. Primers were designed to span at least one intron and were as follows; beta-actin: forward 5' TGCGTGACATCAAAGAGAAG and reverse 5'GA TGCCAGAAGATTCCATA, p21: forward 5'CTCCTG TGGGCACTTTAGGG and reverse 5'TGTCGCTGT CCTGCACTCT, Gadd45 $\alpha$ : forward 5'CTGGAGGAA GTGCTCAGCAA and reverse 5'GGTCGACATTGA GCAGCTTG, Bax: forward 5'TGCCCGAGTTAATC AGAACCA and reverse 5'GGACTCCAGCCACAAA GATAGT, Puma: forward 5'CGGAGACAAGAAGAG CAGCA and reverse 5'TAGTTGGGCTCCATTTCGG G, Mdm2: forward 5'CAGTCTGAGTGAAGATGGG CA and reverse 5'AGCTAAGGAGATCTCAGGGT CT, p53: forward 5'CCAACACAAGCTCCTCTCCC and reverse 5'ATTCGCGTCCTGAGCATCC (metabion international AG and Eurofins Genomics). For each gene the PCR product was cloned into pJet-plasmid as recommended by CloneJET PCR Cloning kit manual and used in qPCR to make a standard curve. Results were analyzed with LightCycler 96 system software.

\section{Propidium iodide flow cytometry}

Forty thousand cells were plated on 6 well plates and treated with $20 \mu \mathrm{M}$ etoposide the next day. $24 \mathrm{~h}$ after the treatment fresh cell culture media was changed and first samples were collected to $70 \% \mathrm{EtOH}$. Similarly $48 \mathrm{~h}$ and $72 \mathrm{~h}$ post-treatment samples were collected and stored in ethanol. Before the flow cytometry cells were resuspended into propidium iodide $(100 \mu \mathrm{g} / \mathrm{ml})$ and RNAse A $(100 \mu \mathrm{g} /$ $\mathrm{ml}$ ) (Thermofisher). For each sample 10,000 cells were recorded with FACSCalibur. Flow cytometry results were analyzed with Flowing Software 2.5.1.

\section{Additional files}

Additional file 1: Chernobyl and control fibroblasts are able to adjust to constant exposure to small concentrations of oxidant. The oxidant was added every other day for four times before scoring the wells that were $100 \%$ confluent a day after the last exposure. The results are from three separate experiments using the eight Chernobyl $(N=24)$ and eight control cell lines $(N=24)$. Variation is shown by standard deviation. (PDF $28 \mathrm{~kb}$ )

Additional file 2: The repair efficiency of nicked, oxidized, or linear plasmids is similar in control and Chernobyl bank vole fibroblasts. For host-cell reactivation assay, 5000 cells were plated on 96 well plate, treated next day with $20 \mu \mathrm{M}$ etoposide for 8 hours, and then transfected with pGL3 (Promega) plasmid treated either with Nb.Bsml that nicked the plasmid coding sequence three times, with HindIII that linearized the plasmid after promoter sequence, or with 50 MM FeSO4 and $1 \mathrm{mM} \mathrm{H} 2 \mathrm{O} 2$, which created oxidative damage on the plasmid. To control transfection efficiency cells were transfected also with pNL1.1 nano-luc vector. Luciferase expression was analysed $24 \mathrm{~h}$ after transfection with Nano-Glo DualLuciferase reporter assay system as suggested by the manufacturer
(Promega). The bar charts show the relation of standardized treated to standardized untreated plasmid expression. The results are from four separate experiments using the eight Chernobyl $(N=32)$ and eight control cell lines $(N=32)$. Variation is shown by standard deviation. (PDF $27 \mathrm{~kb}$ )

Additional file 3: Etoposide induces apoptosis in bank vole fibroblasts. We treated the cells with DMSO or $20 \mu \mathrm{M}$ of etoposide for $24 \mathrm{~h}$, replaced the media, and collected samples $72 \mathrm{~h}$ post-treatment for propidium iodide and Annexin $V$ flow cytometry with eBioscience Annexin $V$ apoptosis Detection kit FITC as recommended by the manufacturer. The figure shows one control and one Chernobyl cell line. The percentage of healthy cells are shown in the lower-left corner, necrotic cells in the upper-left corner, and apoptotic cells at right. (PDF 66 kb)

Additional file 4: The trapping locations of the bank voles used in this study for fibroblast isolation. The green circles present the location at Kiev control area (average site radiation $0.2 \mu \mathrm{Sv} / \mathrm{h}$ ) where the control voles were trapped and the red circle denotes the site where Chernobyl voles were caught (average site radiation $21 \mu \mathrm{Sv} / \mathrm{h}$ ). Black dashed line indicates the $30 \mathrm{~km}$ Chernobyl exclusion zone. CNPP with a red triangle shows the location of the Chernobyl nuclear power plants. A map of Ukraine as an inset show by a red square the location of Chernobyl area. Map was created with ESRI ArcGIS 10.0. Satellite imagery @ CNES/Airbus DS, Earthstar Geographics. Source: Esri, DigitalGlobe, GeoEye, i-cubed, Earthstar Geographics, CNES/Airbus DS, USDA, USGS, AEX, Getmapping, Aerogrid, IGN, IGP, swisstopo, and the GIS User Community | Esri, HERE, DeLorme. (PDF 106 kb)

\section{Acknowledgements}

We are grateful to Virpi Glumoff (University of Oulu) for allocating facilities for the cell culture work and guidance with the flow cytometry and AnnaLeena Manninen, Miika Nieminen, Ilpo Pelkonen, and Eeva-Riitta Savolainen (University of Oulu, University Hospital of Oulu, and Nordlab) for access to the cell irradiator. We are also grateful to Iryna Kozeretska (Taras Shevchenko National University of Kyiv) for the laboratory facilities at Ukraine. We acknowledge Gennadi Milinevsky, Igor Chizhevsky, Kati Kivisaari, and Zbyszek Boratyński for help in organizing fieldwork in Ukraine. We thank reviewers for their constructive comments.

\section{Funding}

This research was supported by a Kone Foundation grant for JJ. The funding body had no role in in the design of the study and collection, analysis, and interpretation of data or in writing the manuscript.

\section{Availability of data and materials}

The datasets used and analysed during the current study are available from the corresponding author on reasonable request. Materials are available on reasonable request.

\section{Authors' contributions}

VM Performed qPCR and Annexin V FACS analysis and contributed to the writing of the manuscript. JK designed GPCR experiments and contributed to the writing of the manuscript. AL designed and performed on site animal collection and contributed to the writing of the manuscript. ET performed the on site animal collection and animal treatments. TM established the study site and methods in Ukraine and contributed to the writing of the manuscript. PCW Designed the on site animal collection and contributed to the writing of the manuscript. JJ Designed and performed the experiments, interpret and analyzed the results, and wrote the manuscript. All authors read and approved the final manuscript.

\section{Ethics approval}

All procedures complied with the legal requirements and international guidelines for the use of animals in research. All necessary permissions for the experiments were obtained from the Animal Experimentation Committee (permission no. ESAVI/7256/04.10.07/2014).

\section{Consent for publication}

Not applicable.

\section{Competing interests}

The authors declare that they have no competing interests. 


\section{Publisher's Note}

Springer Nature remains neutral with regard to jurisdictional claims in published maps and institutional affiliations.

\section{Author details}

'Department of Ecology and Genetics, University of Oulu, Fl-90014 Oulu, Finland. ${ }^{2}$ Institute of Biology and Medicine, Taras Shevchenko National University of Kyiv, Kyiv UA-03022, Ukraine. ${ }^{3}$ Department of Biological and Environmental Science, University of Jyväskylä, Fl-40014 Jyväskylä, Finland.

Received: 11 May 2018 Accepted: 20 August 2018

Published online: 29 August 2018

\section{References}

1. Chesser RK, Bondarkov M, Baker RJ, Wickliffe JK, Rodgers BE. Reconstruction of radioactive plume characteristics along Chernobyl's western trace. J Environ Radioact. 2004;71:147-57.

2. Møller AP, Mousseau TA. Strong effects of ionizing radiation from Chernobyl on mutation rates. Sci Rep. 2015;5:8363.

3. Einor D, Bonisoli-Alquati A, Costantini D, Mousseau TA, Møller AP. Ionizing radiation, antioxidant response and oxidative damage: a meta-analysis. Sci Total Environ. 2016:548-549:463-71.

4. Deryabina TG, Kuchmel SV, Nagorskaya LL, Hinton TG, Beasley JC, Lerebours A, et al. Long-term census data reveal abundant wildlife populations at Chernobyl. Curr Biol. 2015;25:R824-6.

5. Yablokov AV, Nesterenko VB, Nesterenko AV. Consequences of the Chernobyl catastrophe for the environment. Ann N Y Acad Sci. 2009;1181:221-2.

6. Møller AP, Mousseau TA. Species richness and abundance of forest birds in relation to radiation at Chernobyl. Biol Lett. 2007;3:483-6.

7. Baker RJ, Hamilton MJ, Van den Bussche RA, Wiggins LE, Sugg DW, Smith $\mathrm{MH}$, et al. Small mammals from the most radioactive sites near the Chernobyl nuclear power plants. J Mammal. 1996;77:155-70.

8. Møller AP, Mousseau TA. Are organisms adapting to ionizing radiation at Chernobyl? Trends Ecol Evol. 2016;31:281-9.

9. Kovalchuk I, Abramov V, Pogribny I, Kovalchuk O. Molecular aspects of plant adaptation to life in the Chernobyl zone. Plant Physiol. 2004;135:357-63.

10. Boubriak II, Grodzinsky DM, Polischuk VP, Naumenko VD, Gushcha NP, Micheev AN, et al. Adaptation and impairment of DNA repair function in pollen of Betula verrucosa and seeds of Oenothera biennis from differently radionuclide- contaminated sites of Chernobyl. Ann Bot. 2008;101:267-76.

11. Klubicová K, Danchenko M, Skultety L, Berezhna W, Uvackova L, Rashydov $N M$, et al. Soybeans grown in the Chernobyl area produce fertile seeds that have increased heavy metal resistance and modified carbon metabolism. PLoS One. 2012:7:e48169.

12. Meeks HN, Wickliffe JK, Hoofer SR, Chesser RK, Rodgers BE, Baker RJ. Mitochondrial control region variation in bank voles (Clethrionomys glareolus) is not related to Chernobyl radiation exposure. Environ Toxicol Chem. 2007:26:361-9.

13. Geras'kin SA, Fesenko SV, Alexakhin RM. Effects of non-human species irradiation after the Chernobyl NPP accident. Environ Int. 2008:34:880-97.

14. Ryabokon NI, Goncharova Rl. Transgenerational accumulation of radiation damage in small mammals chronically exposed to Chernobyl fallout. Radiat Environ Biophys. 2006;45:167-77.

15. Rodgers $B E$, Baker RJ. Frequencies of micronuclei in Bank voles from zones of high radiation at Chornobyl, Ukraine. Environ Toxicol Chem. 2000;19:1644-8.

16. Lehmann P, Boratyński Z, Mappes T, Mousseau TA, Møller AP. Fitness costs of increased cataract frequency and cumulative radiation dose in natural mammalian populations from Chernobyl. Sci Rep. 2016;6:19974.

17. Baker RJ, Dickins B, Wickliffe JK, Khan FA, Gaschak S, Makova K, et al. Elevated mitochondrial genome variation after 50 generations of radiation exposure in a wild rodent. Evol Appl. 2017;10:784-91

18. Woods D, Turchi JJ. Chemotherapy induced DNA damage response Convergence of drugs and pathways. Cancer Biol Ther. 2013;14:379-89.

19. Shin HJ, Kwon HK, Lee JH, Anwar MA, Choi S. Etoposide induced cytotoxicity mediated by ROS and ERK in human kidney proximal tubule cells. Sci Rep. 2016:26:34064.

20. Sugihara K, Gemba M. Modification of cisplatin toxicity by antioxidants. Jpn J Pharmacol. 1986:40:353-5.

21. Minotti G. Anthracyclines: molecular advances and pharmacologic developments in antitumor activity and cardiotoxicity. Pharmacol Rev. 2004: 56:185-229.
22. Matson CW, Rodgers BE, Chesser RK, Baker RJ. Genetic diversity of Clethrionomys Glareolus populations from highly contaminated sites in the Chornobyl region, Ukraine. Environ Toxicol Chem. 2000;19:2130-5.

23. Boratyński Z, Lehmann P, Mappes T, Mousseau TA, Møller AP. Increased radiation from Chernobyl decreases the expression of red colouration in natural populations of bank voles (Myodes glareolus). Sci Rep. 2014;4:7141.

24. Galván I, Bonisoli-Alquati A, Jenkinson S, Ghanem G, Wakamatsu K, Mousseau TA, et al. Chronic exposure to low-dose radiation at Chernobyl favours adaptation to oxidative stress in birds. Funct Ecol. 2014;28:1387-403.

25. Møller AP, Surai P, Mousseau TA. Antioxidants, Radiation and mutation as revealed by sperm abnormality in barn swallows from Chernobyl. Proc $R$ Soc B Biol Sci [Internet]. 2005;272:247-53.

26. Møller AP, Karadas F, Mousseau TA. Antioxidants in eggs of great tits Parus major from Chernobyl and hatching success. J Comp Physiol B Biochem Syst Environ Physiol. 2008:178:735-43.

27. de Toledo SM, Asaad N, Venkatachalam P, Li L, Howell RW, Spitz DR, et al. Adaptive responses to low-dose/low-dose-rate gamma rays in normal human fibroblasts: the role of growth architecture and oxidative metabolism. Radiat Res. 2006;166:849-57.

28. Loseva O, Shubbar E, Haghdoost S, Evers B, Helleday T, Harms-Ringdahl M. Chronic low dose rate ionizing radiation exposure induces premature senescence in human fibroblasts that correlates with up regulation of proteins involved in protection against oxidative stress. Proteomes. 2014;2:341-62.

29. Tseng BP, Lan ML, Tran KK, Acharya MM, Giedzinski E, Limoli CL. Characterizing low dose and dose rate effects in rodent and human neural stem cells exposed to proton and gamma irradiation. Redox Biol. 2013;1:153-62.

30. Yentrapalli R, Azimzadeh O, Barjaktarovic Z, Sarioglu H, Wojcik A, HarmsRingdahl $\mathrm{M}$, et al. Quantitative proteomic analysis reveals induction of premature senescence in human umbilical vein endothelial cells exposed to chronic low-dose rate gamma radiation. Proteomics. 2013;13:1096-107.

31. Lee JM, Bernstein A. P53 mutations increase resistance to ionizing radiation. Proc Natl Acad Sci U S A. 1993;90:5742-6

32. Shu HK, Kim MM, Chen P, Furman F, Julin CM, Israel MA. The intrinsic radioresistance of glioblastoma-derived cell lines is associated with a failure of p53 to induce p21(BAX) expression. Proc Natl Acad Sci U S A. 1998:95:14453-8.

33. Ashur-Fabian O, Avivi A, Trakhtenbrot L, Adamsky K, Cohen M, Kajakaro G, et al. Evolution of p53 in hypoxia-stressed Spalax mimics human tumor mutation. Proc Natl Acad Sci. 2004;101:12236-41.

34. DeWoody JA. Nucleotide variation in the p53 tumor-suppressor gene of voles from Chernobyl, Ukraine. Mutat Res - Genet Toxicol Environ Mutagen. 1999:439:25-36

35. Garnier-Laplace J, Geras'kin S, Della-Vedova C, Beaugelin-Seiller K, Hinton TG, Real $\mathrm{A}$, et al. Are radiosensitivity data derived from natural field conditions consistent with data from controlled exposures? A case study of Chernobyl wildlife chronically exposed to low dose rates. J Environ Radioact. 2013;121:12-21.

36. Seluanov A, Vaidya A, Gorbunova V. Establishing primary adult fibroblast cultures from rodents. J Vis Exp. 2010;44:2033.

Ready to submit your research? Choose BMC and benefit from:

- fast, convenient online submission

- thorough peer review by experienced researchers in your field

- rapid publication on acceptance

- support for research data, including large and complex data types

- gold Open Access which fosters wider collaboration and increased citations

- maximum visibility for your research: over $100 \mathrm{M}$ website views per year

At BMC, research is always in progress.

Learn more biomedcentral.com/submissions 